\title{
Influence of Feed Restriction on Plane of Nutrition and Carcass Parameters in Ram Lambs
}

\author{
B. Sivanagendra Babu, M.V.A.N. Suryanarayana*, E. Raghava Rao and P. Asha Latha
}

Sri Venkateswara Veterinary University, Department of Livestock Farm Complex, Tirupati (A P), India

*Corresponding author

\begin{tabular}{l} 
K e y w o r d s \\
$\begin{array}{l}\text { Feed restriction, } \\
\text { Realimentation, } \\
\text { Carcass parameters, } \\
\text { cost/kg gain, Plane of } \\
\text { nutrition }\end{array}$ \\
\hline Article Info \\
$\begin{array}{l}\text { Accepted: } \\
12 \text { April } 2018 \\
\text { Available Online: } \\
\text { 10 May } 2018\end{array}$ \\
\hline
\end{tabular}

\section{A B S T R A C T}

In a Completely Randomized Design, thirty two ram lambs $(11.3 \mathrm{~kg} \pm 0.3)$ were tested with four feeding regimes to evaluate the effect of feed restriction followed by realimentation on plane of nutrition and carcass parameters. A 8 week restriction period was followed by a 4 week realimentation phase and the animals divided into 4 groups (T1 to T4) were subjected to feed restriction at 0,10,20, and 30 percent, respectively. After realimentation period, slaughtered animals were studied for carcass parameters. The weight of the skin, meat produced and meat to bone ratio were found to be higher $(\mathrm{P}<0.05)$ for maximum restricted animals. No significant differences in DCP and TDN intake (kg/day) were observed among the treatments but tended to be higher in $\mathrm{T}_{4}$ as compared to other treatments. The DE intake (M cal) and $\mathrm{ME}$ intake ( $\mathrm{M} \mathrm{cal}$ ) were higher in $\mathrm{T}_{4}$ and were nonsignificant. Similar trend was observed during realimentation phase also. The total cost of feed consumed per lamb was decreased with the level of restriction increased from $\mathrm{T}_{1}$ to $\mathrm{T}_{4}$. During restriction phase the feed cost / $\mathrm{kg}$ gain per lamb was increased with the level of restriction increased from $\mathrm{T}_{1}$ to $\mathrm{T}_{4}$. During re-alimentation phase, the feed cost $/ \mathrm{kg}$ gain per lamb decreased from $T_{1}$ to $T_{4}$ with increased level of restriction while the feed cost $/ \mathrm{kg}$ gain per lamb was lower in $\mathrm{T}_{4}$ compared to $\mathrm{T}_{1}, \mathrm{~T}_{2}$ and $\mathrm{T}_{3}$. It was concluded that the increase in the feed restriction up to $30 \%$ in diet has improved the carcass yield and also has reduced the cost/kg gain in ram lambs.

\section{Introduction}

The effect of compensatory growth on body composition has been studied by various researchers and conflicting results have been obtained. Some reports have indicated increase in body fat content (Ledin, 1983; Notter et al., 1983) and others have reported increase in the lean tissue of re-alimented animals (Dashtizadeh et al., 2008; Al-selbood, 2009). Some contradictions could be due to different phases of restrictions and realimentation, and different breeds with different maturity age. The existence of an interaction between the plane of nutrition and the physiological age would seem to explain some of the inconsistencies (Tatum et al., 1988).

Compensatory growth manifested is the ability of the animals previously restricted in the feed intake to outgain their better counter parts 
when given free access to good quality feed. Animals subjected to a period of under nutrition often exhibit a very high growth rate during subsequent re-alimentation (Abegaz et al., 1996). This strategy has very important implication in tropical areas where the animals largely depend on grazing natural pasture to support animal production coupled with feed restrictions which occur due to seasonal variations in nutrient quality and quantity of available pasture materials (Anya et al., 2008).

It was reported (Shadnoush et al., 2011; Sami et al., 2013) that the weights of the body and some of the visceral organs decreased during feed shortage and delay in growth will be compensated with re-feeding phases. It was reported (Kamalzadeh and Aouladrabie, 2009) that sheep decrease their maintenance requirement as a result of feed restriction and further it was reported that the experimental conditions like length, severity of feed restriction, type of diet used and environmental conditions were more important than breed body size. The present study was planned to study the effect of feed restriction and re-feeding on the plane of nutrition and carcass parameters in ram lambs.

\section{Results and Discussion}

At the end of digestion trial, after the realimentation phase, four animals per each group were slaughtered by halal method and were compared parameters like body weight, skin, head, legs, viscera and meat to bone ratio were studied (Table 1). The weight of the skin, head, liver, kidney, spleen, meat produced and meat to bone ratio were found to be higher for maximum $(\mathrm{P}<0.05)$ restricted animals. The remaining parameters were comparable among the animals of different treatments were statistically non-significant

No significant differences were found in DCP and TDN intakes (kg/day) among the treatments (Table 2) and were higher in $\mathrm{T}_{4}$ as compared to other treatments. The DE intake ( $\mathrm{M}$ cal) and $\mathrm{ME}$ intake ( $\mathrm{M}$ cal) were higher in $\mathrm{T}_{4}$ as compared to other treatments. However, no significant differences were observed among the treatments during feed restriction. During refeeding process also the same trend was followed.

The animals that were feed restricted to the maximum showed higher weights for visceral organs during re-alimentation phase. Many workers reported the catch-up weight of fat deposits, visceral organs etc. during realimentation after a period of feed restriction (Abouheif et al., 2013; Sami et al., 2013; Alowaimer et al., 2013; Al-selbood, 2009). In the present study the higher weight of the viscera especially liver for the maximum feed restricted group of animals could probably reflects hypertrophy of the liver tissue upon re-alimentation after a phase of feed restriction (Sami et al., 2013). This compensatory growth was explained by Mora et al., (1996) who found that during the first phase of realimentation, energy was diverted mainly to replenish protein and glycogen reserves in the liver tissues. In the present study, the growth performance or live weight gain was predominant and faster for the maximum feed restricted group of animals. Al-owaimer et al., (2013) found that the late developing tissues such as internal fat and stomach compartments in goats and tail fat in sheep (Al-selbood, 2009) were proportionately more affected by the low plane of nutrition during feed restriction. However, it is understood that the early maturing tissues have a priority to take up the limited nutrients from the blood stream and lose less weight during feed restriction and as suggested by Abouheif et al., (2015), the general trend of tissue accretion indicates a different partitioning priority of nutrient intake between carcass and non-carcass components of re-alimented lambs as indicated by an increase in weights and visceral fat. 
Table.1 Carcass yield $(\mathrm{kg})$ during re-alimentation phase among the treatments

\begin{tabular}{|l|c|c|c|c|}
\hline Particulars & $\mathrm{T}_{1}$ & $\mathrm{~T}_{2}$ & $\mathrm{~T}_{3}$ & $\mathrm{~T}_{4}$ \\
\hline Body weight & $19.08 \pm 0.4$ & $19.5 \pm 0.6$ & $20.3 \pm 0.8$ & $20.1 \pm 1.0$ \\
\hline Skin* & $1.38^{\mathrm{b}} \pm 0.04$ & $1.41^{\mathrm{ab}} \pm 0.06$ & $1.49^{\mathrm{a}} \pm 0.04$ & $1.62^{\mathrm{a}} \pm 0.02$ \\
\hline Head* & $1.46^{\mathrm{a}} \pm 0.03$ & $1.54^{\mathrm{a}} \pm 0.03$ & $1.48^{\mathrm{a}} \pm 0.05$ & $1.68^{\mathrm{b}} \pm 0.02$ \\
\hline Legs & $0.57 \pm 0.06$ & $0.61 \pm 0.02$ & $0.69 \pm 0.03$ & $0.66 \pm 0.02$ \\
\hline Liver* & $0.56^{\mathrm{a}} \pm 0.03$ & $0.72^{\mathrm{a}} \pm 0.04$ & $0.63^{\mathrm{a}} \pm 0.04$ & $0.9^{\mathrm{b}} \pm 0.04$ \\
\hline Heart+pericardium* & $0.14^{\mathrm{a}} \pm 0.008$ & $0.15^{\mathrm{a}} \pm 0.01$ & $0.16^{\mathrm{a}} \pm 0.006$ & $0.19^{\mathrm{b}} \pm 0.004$ \\
\hline Kidney* & $0.17^{\mathrm{b}} \pm 0.06$ & $0.2^{\mathrm{ab}} \pm 0.01$ & $0.19^{\mathrm{b}} \pm 0.02$ & $0.25^{\mathrm{a}} \pm 0.01$ \\
\hline Lung+ trachea & $0.48 \pm 0.06$ & $0.44 \pm 0.03$ & $0.53 \pm 0.07$ & $0.65 \pm 0.02$ \\
\hline Spleen * & $0.06^{\mathrm{b}} \pm 0.005$ & $0.07^{\mathrm{ab}} \pm 0.004$ & $0.09^{\mathrm{a}} \pm 0.01$ & $0.1^{\mathrm{a}} \pm 0.008$ \\
\hline
\end{tabular}

${ }^{a b}$ values in a row with different superscripts differ significantly $*(\mathrm{P}<0.05)$

\begin{tabular}{|l|c|c|c|c|}
\hline Particulars & $\mathrm{T}_{1}$ & $\mathrm{~T}_{2}$ & $\mathrm{~T}_{3}$ & $\mathrm{~T}_{4}$ \\
\hline Oesophagus* & $0.22^{\mathrm{b}} \pm 0.008$ & $0.26^{\mathrm{a}} \pm 0.01$ & $0.25^{\mathrm{ab}} \pm 0.02$ & $0.28^{\mathrm{a}} \pm 0.01$ \\
\hline $\begin{array}{l}\text { Rumen+reticulum+* } \\
\text { omasum+abomasums }\end{array}$ & $0.66^{\mathrm{b}} \pm 0.04$ & $0.57^{\mathrm{b}} \pm 0.03$ & $0.69^{\mathrm{a}} \pm 0.03$ & $0.72^{\mathrm{a}} \pm 0.03$ \\
\hline Small intestine & $0.64 \pm 0.04$ & $0.59 \pm 0.03$ & $0.58 \pm 0.06$ & $0.6 \pm 0.1$ \\
\hline Large intestine & $0.3 \pm 0.02$ & $0.28 \pm 0.02$ & $0.27 \pm 0.03$ & $0.31 \pm 0.02$ \\
\hline Thoracic region & $4.66 \pm 0.5$ & $4.3 \pm 0.3$ & $4.92 \pm 0.4$ & $5.1 \pm 0.2$ \\
\hline Abdomen region & $3.8 \pm 0.1$ & $4.3 \pm 0.5$ & $4.5 \pm 0.2$ & $3.8 \pm 0.4$ \\
\hline Empty body weight & $8.5 \pm 0.5$ & $8.7 \pm 0.4$ & $9.4 \pm 0.5$ & $8.9 \pm 0.4$ \\
\hline Meat * & $4.8^{\mathrm{b}} \pm 0.2$ & $5.04^{\mathrm{a}} \pm 0.2$ & $5.6^{\mathrm{a}} \pm 0.3$ & $5.9^{\mathrm{a}} \pm 0.3$ \\
\hline Bone & $3.67 \pm 0.3$ & $3.63 \pm 0.3$ & $3.8 \pm 0.5$ & $2.9 \pm 0.3$ \\
\hline Meat :Bone* & $1.3^{\mathrm{b}} \pm 0.08$ & $1.4^{\mathrm{a}} \pm 0.08$ & $1.5^{\mathrm{a}} \pm 0.2$ & $2.0^{\mathrm{a}} \pm 0.3$ \\
\hline
\end{tabular}

${ }^{\mathrm{ab}}$ values in a row not sharing common superscripts differ significantly $*(\mathrm{P}<0.05)$ 
Table.2 Plane of nutrition

\begin{tabular}{|l|c|c|c|c|}
\hline \multicolumn{5}{|c|}{ Restriction phase } \\
\hline Particulars & $\mathbf{T}_{\mathbf{1}}$ & $\mathbf{T}_{\mathbf{2}}$ & $\mathbf{T}_{\mathbf{3}}$ & $\mathbf{T}_{\mathbf{4}}$ \\
\hline DCP (\%) & $14.53 \pm 0.3$ & $14.72 \pm 0.5$ & $15.12 \pm 0.3$ & $14.8 \pm 0.4$ \\
\hline TDN(kg/day) & $75.99 \pm 0.5$ & $77.11 \pm 0.7$ & $77.69 \pm 0.9$ & $78.94 \pm 1.2$ \\
\hline ME(M cal) & $27.4 \pm 0.9$ & $27.8 \pm 0.4$ & $28.07 \pm 0.8$ & $28.5 \pm 0.7$ \\
\hline DE(M cal) & $33.4 \pm 1.1$ & $33.99 \pm 2.1$ & $34.42 \pm 1.3$ & $34.7 \pm 1.5$ \\
\hline \multicolumn{4}{|c|}{ Realimentation phase } \\
\hline TDN(kg/day) & $77.7 \pm 0.6$ & $78.47 \pm 1.2$ & $79.07 \pm 0.4$ & $80.5 \pm 1.3$ \\
\hline MIE(Mcal) & $28.1 \pm 1.8$ & $28.3 \pm 1.5$ & $28.59 \pm 0.8$ & $29.1 \pm 1.1$ \\
\hline DE(Mcal) & $34.2 \pm 0.9$ & $34.4 \pm 0.7$ & $34.8 \pm 0.5$ & $35.4 \pm 0.7$ \\
\hline
\end{tabular}

The results showed that the lowered maintenance requirement continues during realimentation phase until protein is fully replenished in these organs. In general, early maturing parts (head, feet and visceral organs) have higher priority in usage of available nutrients in blood and are less affected than late maturing parts. These observations are supported by several reports including those of Hornick et al., (2000) and Kamalzadeh et al., (1998) which have shown that growth rate is reduced with a coordinated decrease in tissue turnover but some tissues react more than others. In re-alimentation phase, the reactions were mostly due to the restriction responses of animals and the most affected organs with the greatest retardation, responded faster than those of less affected. These findings are supported by other reports (Hornick et al., 2000; Kamalzadeh et al., 1998; Dashtizadeh, 2008).

\section{Plane of nutrition}

Data on plane of nutrition revealed that the DCP content expressed as \% in the diet consumed or $\mathrm{kg} /$ day was non-significantly higher in $\mathrm{T}_{4}$ as compared to other treatments. This may be attributed to higher $\mathrm{CP}$ digestibility in $\mathrm{T}_{4}$ as compared to other treatments. The present study also indicated that the DCP content expressed as \% in the diet consumed or $\mathrm{kg} / \mathrm{d}$ was higher in ram lambs fed $30 \%$ restriction group compared to control. Further, the DCP intakes in all the treatment groups were higher than the recommended levels of ICAR (2013).

The TDN content expressed as $\%$ in the diet consumed or $\mathrm{kg} /$ day was non-significantly higher in $\mathrm{T}_{4}$. The numerically higher nutrient digestibilities recorded in ram lambs fed $30 \%$ restricted group as compared to others might have resulted in higher TDN content when compared with others. The DE and ME intakes (Mcal) reported in the present study followed similar trends as observed with TDN intakes.

The DCP, TDN and ME intakes per Wkg0.75 as well as calorie protein ratio was higher in ram lambs fed $30 \%$ restricted group as compared to others treatments. This indicated that the ram lambs fed on different dietary treatments were maintained at increasing plane of nutrition. Further, the DCP intakes per $\mathrm{W} \mathrm{kg} 0.75$ as well as calorie protein ratio reported in the present study were higher than the values recommended by ICAR (1998) standards.

The total feed cost in restricted phase showed a decreasing trend from $T_{1}$ to $T_{4}$ and reverse trend was observed during re-alimentation phase. The feed cost per $\mathrm{Kg}$ gain per lamb was maximum for $30 \%$ feed restricted 
animals. The phenomenon restated that animals subjected to a phase of under nutrition often exhibit a very high growth rate during subsequent re-alimentation. Though not much variation was observed regarding the average subabul cost per lamb in realimentation phase, during restriction phase the cost showed more and was nonsignificant.

The expenditure incurred for feed during restriction phase showed a decreased trend with a corresponding decrease in the feed intake. However, reverse trend was observed during re-alimentation phase as the feed intake increased. The maximum restricted group recouped faster with higher feed intake with a corresponding increase in the cost of feed.

It was concluded that the increase in the feed restriction up to $30 \%$ in diet has improved the carcass yield and reduces the cost of production per $\mathrm{kg}$ gain. The cost of feed per $\mathrm{kg}$ gain was 63, 35 and 18 percent less for $\mathrm{T}_{4}$, $\mathrm{T}_{3}$ and $\mathrm{T}_{2}$ as compared to $\mathrm{T}_{1}$ during realimentation phase.

\section{References}

Abegaz S, Tiyo D and Gizachew L 1996 Compensatory growth in Horro lambs of Ethiopia. In: Small Ruminant research and development in Africa. Proceedings of the Third Biennial Conference of the African Small Ruminant Research Network, UICC, Kampala, Uganda ILRI, Nairobi, Kenya 209-213PN.

Abouheif M, Al-Owaimer A, Kraidees M, Hassan Metwally and Shafey T 2013 Effect of restricted feeding and realimentation on feed performance and carcass characteristics of growing lambs. Rev. Brasi de Zootec. 42(2): 95101.
Abouheif M, Al-Sornokh H, Swelum A, Yaqoob H and Abdullah A W 2015. Effect of different feed restriction regimes on lamb performance and carcass traits. Rev. Brasi de Zootec. 44 (3):76-82.

Al-Owaimer, Suliman G, El-Waziry A, Metwally $H$ and Abouheif M 2013 Allometric Growth Patterns of Body and Carcass Components in Aradhi Goat. Int. J.Anim. \& Vet. Adv. 5(5): 183-189, 2013.

Al-Selbood B A 2009 Effect of feeding program on performance and carcass characteristics of Najdi lambs. Ph.D. Thesis. King Saud University, Saudi Arabia.

Anya M I, Edet G D, Nsa E E and Umoren E P 2008 Evaluation of mineral composition of some forage legumes and grasses in tropical high forest zone of cross river state, Nigeria. Nigerian South-East Journal of Agricultural Economics and Extension 8(1\&2) 3337.

Dashtizadeh M 1, Zamiri M J, KamalzadehA and Kamali A 2008 Effect of feed restriction on compensatory growth response of young male goats. Iranian Journal of Veterinary Research, Vol. 9, No. 2, Ser. No. 23, 2008.

Hornick J L, van Eanaeme C, Gerard O, Dufrashe I and Istasse L 2000 Mechanisms of reduced and compensatory growth. Domestic Animal Endocrinology 19 121-132.

I C A R 2013 Nutrition Requirements of Sheep

Kamalzadeh A and Aouladrabiei M R 2009 Effect of restricted feeding on intake, digestion, nitrogen, balance and metabolizable energy in small and large body sized sheep breeds. J. Anim. Sci. 22:667-673.

Kamalzadeh A, Koops W J, van Bruchem J and Bangma G A 1998 Effect of 
duration of feed quality restriction on body dimensions in lambs. J. Anim. Sci.76:735-742.

Ledin 1983 Effect of restricted feed and realimentation on growth, carcass composition and organ growth in lambs. Swed. J. Agric. Res. 13. 175.

Mora O, Shimada A and Ruiz F J 1996 The effect of length and severity of feed restriction on weight, carcass measurements and body composition of goats. J.Agric.Sci. (Camb), 127:549553.
Notter D R, Ferrell C L and Field R A 1983 Effects of breed and intake level on allometric growth patterns in ram lambs. J. Anim. Sci. 56380.

Sami A, Shafey T and Abouheif M 2013 Growth rate of carcass, non-carcass and chemical components of restricted fed and re-alimented growing lambs. Int. J. Agri.bio.15: 307-312.

Tatum J D, Klein J, Williams $\mathrm{F} \mathrm{L}$ and Bowling R A 1988 Influence of diet on growth rate and carcass composition of steers differing in frame size and muscle thickness. J. Anim. Sci. 66:1942.

\section{How to cite this article:}

Sivanagendra Babu, B., M.V.A.N. Suryanarayana, E. Raghava Rao and Asha Latha, P. 2018. Influence of Feed Restriction on Plane of Nutrition and Carcass Parameters in Ram Lambs. Int.J.Curr.Microbiol.App.Sci. 7(05): 1708-1713. doi: https://doi.org/10.20546/ijcmas.2018.705.200 